\title{
POPULATION PROJECTION FOR HUNGARY AND ITS RELATION WITH CLIMATE CHANGE
}

\author{
Gábor Király, Márton Czirfusz, Bálint Koós, Gergely Tagai, Annamaria Uzzoli \\ Centre for Economic and Regional StudiesHungarian Academy of Sciences Hungary \\ Budaörsi út 45, H-1112 Budapest: Hungary \\ kiralyg@rkk.hu, czirfusz@rkk.hu, koosb@rkk.hu, tagai@rkk.hu, uzzoli@rkk.hu
}

\begin{abstract}
This paper presents some of the most important results and theoretical as well as methodological experiences of a recent research project into long-term socio-economic forecasting in relation to climate change in Hungary. The main empirical part contains a population projection of demographic processes in Hungary until 2051, on the scale of LAU-1. This model focuses on demographic processes with the statistical indicators of population by number and age groups. The main added value of the project is that it delivers spatially disaggregated data on future socio-economic, in particular demographic trends in Hungary and links these processes to climate change through heat waves, thereby addressing the needs of social groups which are most vulnerable to climate change.
\end{abstract}

Key words: climate change, socio-economic processes, population projection, heat wave, health, vulnerability, Hungary.

\section{Introduction}

Research into regional and local impact of global climate change and the multi-approach interpretation and evaluation of socio-economic and policy implications of such change have grown in importance recently (see for example van Staden \& Musco 2010; Salih 2013). Extreme weather as an outcome of climate change has become an increasingly serious challenge for local communities, with society and economy becoming increasingly vulnerable, and successful adaptation to changing conditions and circumstances growing in importance. Climate change, adaptation to such change and related development policy interventions require scientific evidence to an increasingly large extent because such evidence provides information that enables decision-makers to design mitigation and adaptation measures.

Despite the self-evident interrelations between socio-economic and climate change, it remains scarcely known what is the number of people affected by climate change and where exactly do they live. To narrow down this empirical gap, we need thorough population projections, taking spatial aspects into account, and we have to focus on the number of such groups and their share in the society, increasingly affected by climate change.

This paper aims to address this empirical gap by linking population and climate change, both theoretically and empirically. It shows the results of a recent population projection for Hungary 
at the district (LAU-1) level, and brings these results back to the discussion on climate change, by pointing out its possible effects, and also policy implications.

The structure of this paper is as follows. First, we discuss its aims and scope, supplementing it with a review of literature on how the interrelations between population and climate change are conceived in academic and policy discussions. Second, the methodology of building our population projection is discussed. The following part summarises main results of the population projection and refers to its possible causes and consequences. In the next section, we link the results of the population projection to climate change: we focus on one specific aspect, namely elderly people affected by the increasing number of heat waves in Hungary. The last part summarizes the policy implications of our research, and reviews some planning documents, showing how they combine the effects and causes of population dynamics and climate change.

\section{Theory, aims and scope of this paper}

To understand the interrelations between population dynamics and climate change it is important to identify different theoretical approaches to understanding and modelling the two phenomena in academic and policy discussions. We briefly outline three selected approaches (Fig. 1).

The first, mainstream approach in climate change research models future climate change using socio-economic assumptions as external variables in the calculations. One of the main knowledge producers in this field is IPCC. In IPCC reports, different scenarios (so-called "representative concentration pathways") assume different "anthropogenic" (socio-economic) drivers leading to rising greenhouse gas emissions which have different impacts on the society and economy. For example, according to the 5th IPCC report, climate change is one of the biggest health hazards for the population of the 21st century (IPCC 2014). Therefore, preparations will have to be made to address the increasingly acutely-felt effects of changing climatic and meteorological conditions and weather. This underscores the importance of making projections and constructing scenarios for Hungary's socio-economic processes, to draw attention of both policy makers and the population to likely interdependencies and expected consequences regarding climate change.

In Hungary, this approach is followed by recent updates of various regional climate models with different scenarios (IIly et al. 2015; Pieczka et al. 2015). Forecasting the risks posed by climate change for the society is a particularly topical issue in Hungary for two main reasons. Firstly, because the 1.4 to $2.6^{\circ} \mathrm{C}$ increase in mean yearly temperature expected to materialise by the middle of the century will have a significant impact on society and economy, and secondly, because Hungary's exposure to climate change is significant, owing mainly to a rise in mean temperature and major temporal variations in precipitation. In addition to the prevention of climate change, it is of particular importance for Hungarian policy makers to create appropriate conditions for adapting to climate change consequences and for exploiting the available opportunities.

The second approach is mainly followed in socio-economic modelling. Here the basic assumption is that climate change cannot be forecasted without first forecasting socio-economic processes. Climate change is thus treated as a variable external to socio-economic processes. This understanding is most common, because socio-economic implications of climate change are difficult to identify as numerous changes may materialise in the economy, in demography and in social phenomena; direct impact of climate change is difficult to assess. 
Despite this, climate change is one of the key factors affecting processes in the realm of society and economy. It is also true that there are economic sectors, such as agriculture, forestry, energy management, infrastructure, healthcare and tourism, that are more susceptible to the impact of climate change than others. Some recent examples of Hungarian sectoral case studies are Bobvos, Fazekas \& Páldy (2015) for health (heat-related mortality), and Kovács, Unger \& Szépszó (2015) for tourism. Both studies took into account the spatial differences in the impact of climate change within the country. There are many uncertainties related to the forecasting of socio-economic impact of climate change, and thus we will need to extend the scope of such forecasting, update its methodology and make use of the results obtained previously.

The third approach is followed by recent social science literature, which understands social and climate change as fundamentally the same process. This approach is focused on socio-ecological or political-ecological systems, and it is applied "to evaluate particular causal socio-ecological processes and place them within their broader recursive relationships, while linking them to their broader socio-ecological outcomes" (Birkenholtz 2011: 310). Apart from that aspect, this approach challenges the consensus over nature as being an external conditioning frame for human life; it dissolves the boundaries between natural and social sciences and merges political questions with environmental ones, such as climate change (Swyngedouw 2013).

Approach 1

INPUT (CLIMATE) DATA

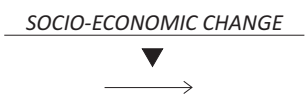

OUTPUT (CLIMATE) DATA

Approach 2

INPUT (SOCIO-ECONOMIC) DATA

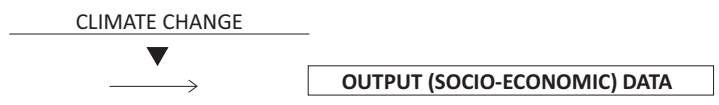

Approach 3

INPUT (SOCIO-ECOLOGICAL) DATA

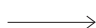

OUTPUT (SOCIO-ECOLOGICAL) DATA

Figure 1. Model logics applied to the relationship between socio-economic spatial processes and climate change

Source: based on Suvák 2015, extended by the authors.

This paper generally follows the second line of argument, by modelling the population change for Hungary and by taking into account the possible effects of climate change. This choice is mainly based on the research design of a larger project that the population projections were a part of. We continue with a brief introduction to this larger project.

Hungary launched a common geo-information system (National Adaptation Geo-information System, NAGIS - http://nater.mfgi.hu/en) in 2016, in order to help decision-makers in implementing local, regional and national adaptation measures to climate change (Orosz et al. 2015). Apart from new data concerning climate change within Hungary, this database consists of different ecological, economic and social data, grouped also according to the CIVAS (Climate Impact and Vulnerability Assessment Scheme) categories, i.e. sensitivity, exposure, adaptive capacity and vulnerability. 
New population projections were an important building block of NAGIS. Although population geographies as a scientific field have already significantly contributed to the understanding of how populations are connected to climate change (Bailey 2010), this approach is rather a novelty in Hungarian academia, despite the emerging debates on the interrelation between migration and climate change (cf. Vág 2010). Population projections underlying this study are based on a sociological approach and methodology, with an emphasis on the presentation of spatial demographic processes at the local scale.

The project modelled the anticipated demographic trends until 2051 at the district (LAU-1) level, and analysed also their interrelations with climate change. Its primary objective was to analyse the geographically varied challenges related to climate change as well as the responses to its likely socio-economic consequences.

\section{Methodology used for the population projection}

This paper focuses mainly on the projection and LAU-1 level presentation of demographic phenomena expected until 2051. Although in our calculation solely demographic variables were used (cf. the second approach identified in Figure 1), the forecasting gives a solid foundation for understanding future environmental (or climate) change effects on population numbers. The socio-economic processes affected by climate change influence individual population groups differently: the results of projections are therefore also available broken down by sex and age group. This means that as we can estimate how many vulnerable people there will be in the future in particular places, we will be able to predict more general trends of future socio-economic change in those geographical locations.

The future size of the population was predicted using the cohort component method. This is a standard population forecasting technique, used for over 100 years (Cannan 1895) and widespread also in the U.N. (United Nations 2015) and the EU (Giannakouris 2010), and used in Hungarian population projections as well (Földházi 2013). The model relies on major indicators (total fertility rate, life expectancy at birth, and net migration rate) of the components of demographic change (fertility, mortality, and migration). In the model for population size throughput, the number and ratio of new entrants is determined by births. The demographic population life cycle for any given population cohort is determined by mortality and survival probabilities. This is further shaped by the age-specific attributes of migration. The resulting model is a step-by-step one in which the size of the population is adjusted for the number of births, deaths, individuals surviving to the next stage of their life, immigrants and emigrants at every step. Thus, population sizes can be easily projected to the very end of the projection period (in our case, until 2051).

Following standard forecasting methodology, we analysed several development paths of future population numbers, also in order to understand the internal variance of the models and the reliability of results. Three different scenarios were analysed as part of the project: a main scenario, a low one and a high one. Hypotheses for the three predictions are as follows (Földházi 2013):

1. Main (medium) scenario: average fertility, average life expectancy and average net rate of migration.

2. Low variant: low fertility, low life expectancy and low net rate of migration.

3. High variant: high fertility, high life expectancy and high net rate of migration.

The main scenario contains the most likely hypotheses for future trends in the size of the population (Földházi 2013). The other two variants predict trends that are either more or less 
favourable than those projected in the main scenario. Together, the three models determine the possible "boundaries" of population change within the given projection periods. In this paper, we will briefly discuss key differences between the three scenarios, focusing on the results foreseen in the main scenario.

Population projections were carried out in a breakdown by sex, 5-year age groups, and LAU-1 level districts. The starting years for the projections were 2001, 2006 (these two being the starting years for the two-cycle benchmark period), and 2011. Model simulations were based on the following input data (Tagai 2015):

1. Population numbers for the starting years, which are official census data for 2001 and 2011, and official register-based data for 2011.

2. Birth data: We followed the scenarios of EUROPOP 2013 as well as Eurostat's regular population projections, both to gain information on the starting year and the benchmark period, and to formulate hypotheses for future age-specific fertility. Future data on the country as a whole were made proportionate to the current district-level distribution (http://ec.europa.eu/eurostat/ data/database?node_code=proj). The underlying assumption was that regional differences in fertility would not change in the future.

3. Survival rates: These determine the size and the age-group distribution of the population surviving the next five-year period. Survival rates could be calculated outside the cohort component model and, along with other indicators and ratios (e.g. life expectancy at a certain age, number of years lived in a certain age group, and mortality rates) are included in mortality tables. Mortality tables for the reference period were based on data on mortality in individual age groups, while hypotheses on future mortality drew on relevant data of EUROPOP 2013 and were down-scaled to the district level. Subsequently, observation-based data series on survival rates and assumptions for the future served as input data for population projections.

4. Migration factors: The migration component is indirectly built into the calculation. The basis for this is a separate simulation which compares facts for benchmark periods with the value of population size throughput, calculated on the basis of fertility and survival rates for the same periods. Population excess or population deficiency, given by the difference between observations and simulation-based data, is the average net migration rate.

Projections for LAU-1 level districts are composed of calculations for 176 territorial units. Standard forecasting applications, however, could only treat one territorial unit in the calculation. We searched for an application which has easy-to-satisfy data needs and which could manage the joint simulation of the districts. It was also important to be able to run the calculations repeatedly to test various hypotheses. Finally, we opted for a modified Excel-based application designed by Timothy Chapin, Professor of Urban \& Regional Planning at Florida State University (http://www.demog.berkeley. edu/ eddieh/toolbox.html). Chapin's original application was used to run simultaneous projections for separate ethnic groups; by analogy, we replaced ethnic groups with our territorial units. This model was able to recalculate population projections simultaneously at the level of Hungarian districts through a minor transformation of input data and the relevant hypotheses.

In the next section, we discuss the main results of our population projection and compare this with previous research in the field. After that, we continue with linking population projections with climate change. For this part, we made further calculations, using the results of the main scenario, by placing special emphasis on projections for the most vulnerable age groups as regards one aspect of climate change, namely heat waves. 


\section{Results of the population projection}

The results of our population projections covering the entire country (right column of Table 1) are very similar to those published previously by the Demographic Research Institute at the Hungarian Central Statistical Office (middle column of Table 1).

The population of Hungary at the time of 2011 census was 9.94 million people, and it had been constantly decreasing since 1981 (the country had 10.7 million inhabitants then). In all the models and all scenarios, in 2051 Hungary's population will be between 7.5 and 9 million: according to the low variant proposed by the Demographic Research Institute, in 2051 the population of Hungary will be approximately 7.5 million. By contrast, in the high variant, it will be around 9 million. The results presented by the two institutions show no significant differences between individual values of the main scenario used for further calculations - they both estimated the population size at 8.3 to 8.5 million in 2051; with an increasing pace of population decrease between 2011 and 2051.

Table 1. Predicted population numbers for Hungary in 2051 - comparing different scenarios and projections

\begin{tabular}{|c|c|c|}
\hline Scenario & $\begin{array}{c}\text { Demographic Research Institute, } \\
\text { Hungarian Central Statistical Office }\end{array}$ & $\begin{array}{c}\text { Centre of Economic and Regional Studies, } \\
\text { Hungarian Academy of Sciences }\end{array}$ \\
\hline Main scenario & $8,295,579$ & $8,437,955$ \\
\hline Low variant & $7,542,438$ & $8,004,576$ \\
\hline High variant & $8,773,097$ & $9,072,214$ \\
\hline
\end{tabular}

Source: Földházi 2013, supplemented with own calculations.

It is not only the number of population living in Hungary which will change, but also its internal age, gender and spatial structure. In this paper we discuss in detail how the spatial structure of aging will change until 2051, as this is, to our understanding, a key issue if we consider the relationship between population projections and climate change. In this section, we outline the main trends, and then link the results of population projection to the effects of climate change.

Aging will have affected the entire country by mid-century (Fig. 2). The most recent census data have revealed that in 2011 the number of people over 65 was already higher in the country than the number of people under 15 . In 2011, the share of those aged $65+$ in the total population reached $25 \%$ in a few districts. Based on our projections, however, the share of the elderly in district population will increase consistently, starting from 2016. By 2026 and 2036 it will have exceeded respectively $25 \%$ and $30 \%$ in a growing number of districts. Starting from the 2040 s, at least one-third of the population will be aged $65+$ in most districts.

The projections outline a specific spatial structure in terms of location of the elderly in 2051. According to the calculations, the share of the elderly will not be rising evenly across the country: it will be lowest in the middle part of the country (Budapest and its suburban zone), in the environs of larger cities, and in north-eastern Hungary. Aging will be more rapid in the western parts of the country - the share of elderly population will exceed $30 \%$ in these areas (Fig. 2). 

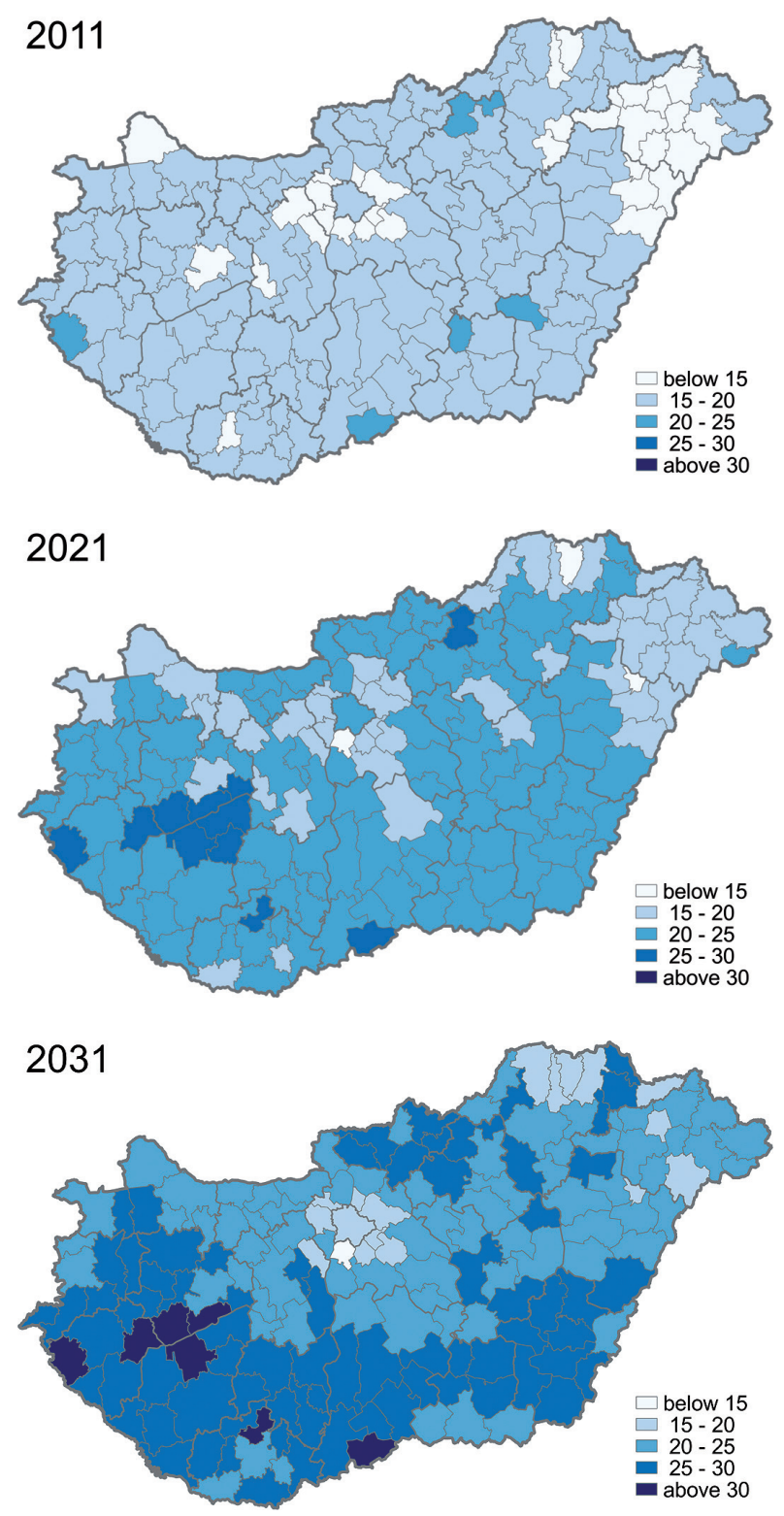

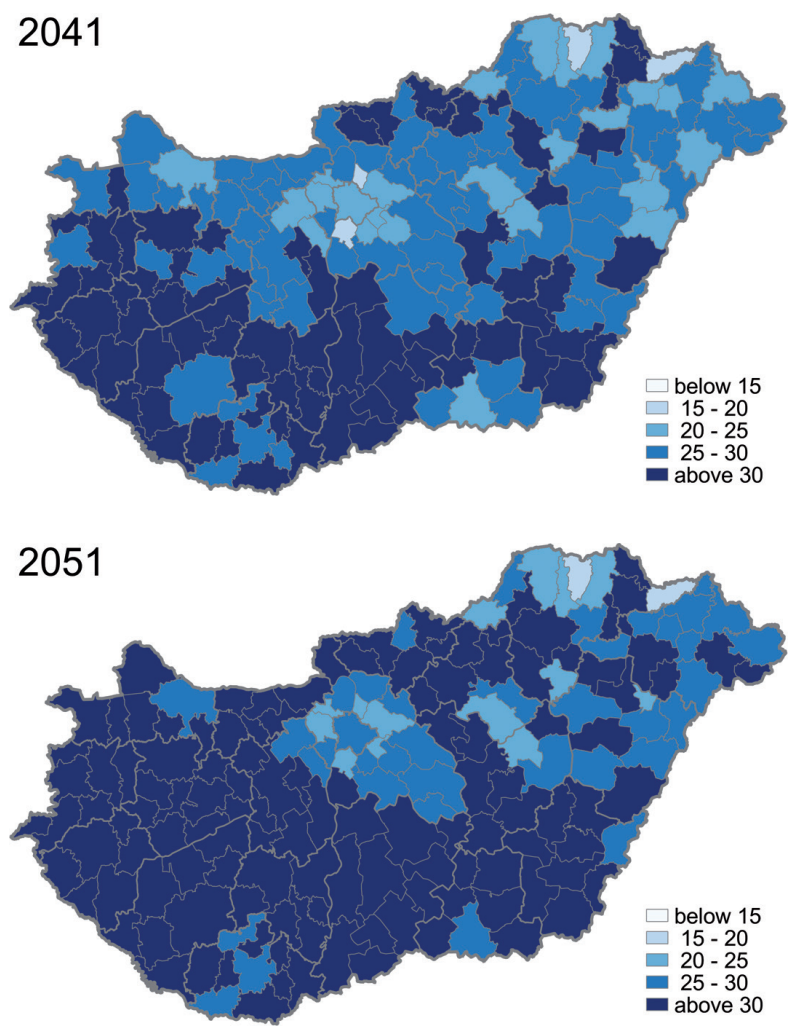

Figure 2. Share of those aged 65+ in the total population (\%) in Hungarian districts between 2011 and 2051 Source: authors' own compilation.

Although we presented only some of the results of the main scenario of our LAU-1 level population projections, the projected future paths of population development in individual Hungarian regions made us take into careful consideration the socio-demographic challenges we will face until 2051. The spatial differences of aging, especially, will make a growing number of people increasingly vulnerable and dependable on social security and social assistance. As the number of elderly population will grow in the future, easing of bottlenecks in elderly care and in health-related public services will become an important policy aspect. In addressing such problems, due account must be taken of possible effects that climate change will have on different groups of the society. This is the question we turn to in the next section.

\section{Health vulnerability and climate change - Demography-related consequences of heat waves}

In this part, we combine the results of our population projection with the foreseen impacts of climate change in Hungary. The majority of Hungarian literature and policy documents in this area follow an approach that starts from the current socio-economic trends and climate; then the projected climate change are discussed and assumptions are made about its impact on social and economic 
variables. Our paper moves beyond this understanding by modelling demographic change and combining these with the possible effects of climate change. Thereby we might introduce more nuanced descriptions of the future adaptation measures.

One of the fields in literature bringing the climate change and the demographic change together (at least in the Hungarian case, and in other countries with temperate climates) is the effect of heat waves on the elderly population. We have seen in the previous section that aging will be an important issue in the future Hungary. In this section, we combine these data with predictions on future heat waves and their effects.

In general, the effects of climate change expected to materialise in Hungary are likely to include an increase in the number of heat waves, more extreme variations in river flow, and more frequent and intense storms (Pálvölgyi et al. 2011; Pálvölgyi \& Hunyady 2008). The last two aspects have less dramatic effects on specific demographic groups, although they might influence the internal migration patterns. It is more important to look at the first factor, i.e. the increasing number of heat waves.

In Hungary, climate change increases the likelihood of heat waves, which pose a risk mainly to the elderly, and mainly in the realm of health. According to the forecasts, the adverse impact of heat waves on health will affect most of Hungary's territory (although not evenly), both because of the climatic variables and the high number of the elderly.

The issue of harmful effects of climate change on health has been addressed regularly in Hungary since the early 2000s (e.g. Páldy et al. 2005). The evaluations of the impact of climate change on health were mostly aimed at assessing the health risks posed by the rising mean daily temperature. Today, the exposure to climate change and the interpretation of susceptibility to its impact on health are topical issues in studies using health indicators to gauge climate change-related vulnerability. The direct, immediate effects on health caused by extreme weather events linked to climate change include nausea and a rise in the number of deaths caused by heat waves (McMichael 2003). The rise in the rate of deaths caused by heat waves is called excess death rate.

Studies on health risks caused by heat waves are particularly abundant in Hungarian scientific literature. They draw attention to the increased likelihood of the occurrence of deaths and the development of medical conditions (e.g. heat stress, cardio-vascular diseases and related deaths, respiratory complaints, infections and skin rashes) triggered by heat waves in the summer, with young children, the elderly, the chronically ill and other multiple disadvantaged groups being exposed to particularly high risks (Páldy \& Bobvos 2014).

Under some climate scenarios, between 2021 and 2050 there will be a $45 \%$ increase in the frequency of heat alerts (announced in Hungary when the mean daily temperature exceeds $25^{\circ} \mathrm{C}$ on three successive days) across the country (Bartholy et al. 2010; Páldy \& Bobvos 2010) (Fig. 3). $25^{\circ} \mathrm{C}$ seems to be a suitable threshold for identifying an excess death rate. The connection between daily excess mortality and the mean temperature will be stronger in the future: in 2021-2050, an increase of air temperature by $1^{\circ} \mathrm{C}$ will result in $4.9 \%$ increase in daily mortality rate on days with mean temperature $>25^{\circ} \mathrm{C}$ (Bobvos et al. 2014). 


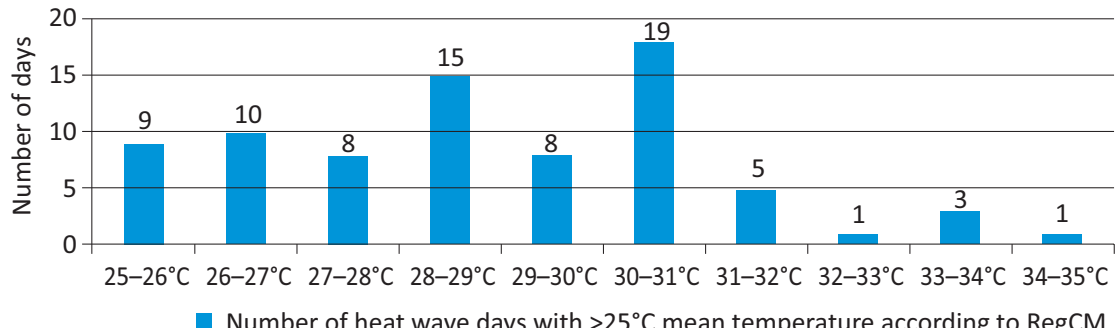

Figure 3. Expected number of heat wave days in Hungary (y-axis) with mean daily temperatures ( $x$-axis) in 2021-2050, in relation to the reference period (1961-1990; RegCM model)

Source: Bartholy et al. 2010; Páldy \& Bobvos 2011.

By comparing daily death rates and meteorological data, Páldy and Bobvos studied the interdependency between temperature and the total daily number of cause-specific deaths in the summer between 1970 and 2000 . They found that a $5^{\circ} \mathrm{C}$ increase in the mean daily temperature raised the death risk (irrespective of the cause of death) significantly, i.e. by $6 \%$, and cardiovascular death risk even more - by approximately 10\% (Páldy \& Bobvos 2010). The most recent calculations estimate that the number of excess deaths is currently 786. As the number of heat wave days will rise by $77 \%$ by $2021-2050$ (Fig. 3), we can expect a $160 \%$ increase in the number of excess deaths due to climate change in Hungary (1697 people annually) - if we assume that sensitivity to heat waves stagnates in the future. The rising number of excess deaths will not be evenly distributed geographically in Hungary: north eastern and southern Hungary record higher growth rates than north western Hungary (Páldy \& Bobvos 2015).

The expected increase in the number of excess deaths due to heat waves will mainly affect the population aged 65 and above. Therefore, during heat alerts close attention must be paid to the chronically ill elderly, who are one of the most vulnerable groups affected by climate change (Bobvos et al. 2015).

\section{Summary and policy outlook}

In this paper we introduced a novel approach and we presented a recent empirical study focusing on how to combine future population trends with possible effects of climate change in Hungary. Although the chosen research design falls short of offering a solid theoretical foundation for integrating complex causal relations between climate and social change into a single model, nevertheless, it might offer new insights and new data for future academic scrutiny and it may contribute to policy change. In this part of our paper we outline some of the linkages to policy and theoretical developments.

The most important policy document in Hungary which combines population forecasts and climate change is the Second National Climate Change Strategy 2014-2025, with an outlook to 2050. A separate chapter of this strategy is devoted to the impact of climate change on human health (NCCS-2 2013). It is pointed out that an increase in the frequency of heat waves is of particular importance for public health in Hungary. The strategy accords priority to protection against heat waves, i.e. to improving the protection measures for both individuals and communities, and to strengthening networks capable of addressing climate-change-related health issues. The latter 
involves both qualitative and quantitative improvement of the health care system in preparation for increased demand on the system due to climate change (e.g. more frequent alerts to ambulances and more frequent hospitalisation during heat waves) and for the organisation of fast and efficient interventions (e.g. heat alerts and preparing the population). Furthermore, a national health care plan based on an improved health care system capable of addressing climate change-related health issues should also be worked out in view of the dangers caused by heat waves. The infrastructural development of social care should also accommodate acceleration in the process of population aging.

With the help of our new data on the LAU-1 level future population change it will be possible to fine-tune these adaptation measures spatially, thereby linking climate change adaptation not only with the national development policy, but also with regional and local level development policies. One of the important means to assist future policy-making is the National Adaptation Geo-Information System and the population projection discussed above is an important building block of this system.

The most important results and experiences of our larger research project will facilitate the adaptation to climate change and its effects, providing a scientific basis for such adaptation. They will also allow for devising and implementation of measures pertaining to individual regions as well as for establishing strategies and similar pilot projects at the regional level, thus improving the skills and abilities of experts and policy-makers, and raising climate awareness of society and local communities. This might be achieved in by other means provided for in sectoral policies. A possible extension of the study is to establish linkages with environmental policy, such as strategic environmental assessment (Varjú 2015). It is also possible to combine the future impact of climate change with energy issues, and particularly related to people living under circumstances of energy poverty (Bouzarovski \& Petrova 2015, Ürge-Vorsatz \& Tirado Herrero 2012). This line of argument opens the field for environmental ethics (Suvák 2013). Another issue for sectoral policies might be to work out heat wave plans at the national and also local level, thereby reducing the vulnerability of the population, as is the case in several countries, for example the United Kingdom (Uzzoli 2015). Table 2 shows the primary responsibilities of national and local authorities. It also spells out what preparations both individuals and organisations can make to reduce health risks and includes specific measures to protect groups that are at risk of heat waves.

Table 2. National and local level actions to reduce heat-health risks

\begin{tabular}{|c|c|c|}
\hline \multirow{2}{*}{ Heat-health risks } & \multicolumn{2}{|c|}{ Actions to consider } \\
\hline & At the national level & At the local level \\
\hline $\begin{array}{l}\text { 1. Increased exposure } \\
\text { to heat }\end{array}$ & $\begin{array}{l}\text { - } \text { create national heat wave plan } \\
\text { - } \text { operate a heat-health watch system } \\
\text { - } \quad \text { establish a heat-health alert system } \\
\text { - } \quad \text { consider changing the date and } \\
\text { location or cancelling public events } \\
\text { in the case of extreme heat alert }\end{array}$ & 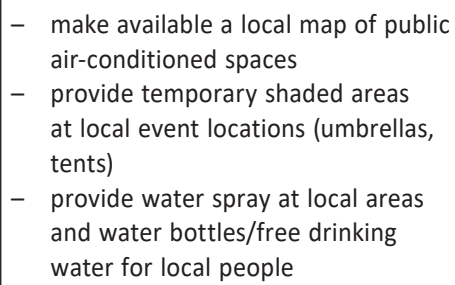 \\
\hline $\begin{array}{l}\text { 2. Communication } \\
\text { disfunctionalities }\end{array}$ & $\begin{array}{l}\text { - } \text { create a national communication } \\
\text { network } \\
\text { - } \quad \text { provide an emergency phone } \\
\text { number }\end{array}$ & $\begin{array}{l}\text { - } \text { inform local people about } \\
\text { heat-health risks and adaption } \\
\text { possibilities through relevant } \\
\text { communication channels }\end{array}$ \\
\hline
\end{tabular}




\begin{tabular}{|c|c|c|}
\hline \multirow{2}{*}{ Heat-health risks } & \multicolumn{2}{|c|}{ Actions to consider } \\
\hline & At the national level & At the local level \\
\hline $\begin{array}{l}\text { 3. Increasing social care } \\
\text { needs }\end{array}$ & 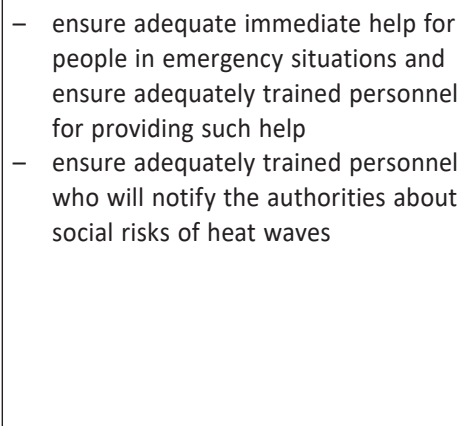 & 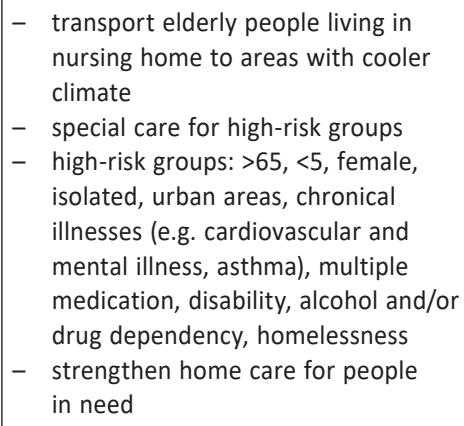 \\
\hline $\begin{array}{l}\text { 4. Increasing health care } \\
\text { needs }\end{array}$ & 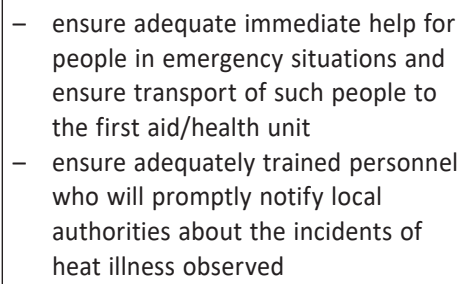 & $\begin{array}{l}\text { - strengthen local health care services } \\
\text { for people in need }\end{array}$ \\
\hline
\end{tabular}

Source: Uzzoli 2015: 123.

Apart from the policy implications there are also important theoretical aspects which will need more consideration in the future. The objectives of the anticipated research continuation are, in a more direct sense, to define the most important health-associated risk factors during heat waves, and to analyse and make projections for trends and regional differences at a district level about the increased number of deaths caused by heat waves. This will bring forward current literature on the geographies of health related to climate change (Curtis \& Oven 2012). The other issue at stake is to understand the interrelation between socio-economic factors and adaptation to climate change in the light of spatial processes. The third group of future research involves more general theoretical considerations. Popke (2016) for example identified significant epistemological, ontological and methodological challenges involved in understanding the hybridity of these socio-ecological changes. It is highly important to allow in climate change debates a wide variety of understandings of the issue (Jankó et al. 2014). Baranyai and Varjú (2015) have demonstrated that there are significant spatial differences among Hungarian adult population in their understanding of climate change and willingness to undertake adaptation measures. These results are also in accordance with other studies on Hungarian farmers (Kulcsár 2014) and with local case studies dedicated to attitudes toward climate change and its variations depending on demographic indicators (Leveleki 2015).

If we are able to combine future trends in population change and understand its complex interrelations with climate change, we will also be able to formulate better ways of adaptation of the population to the spatially unequal consequences of socio-ecological change. 


\section{Acknowledgements}

This study was supported by EEA Grants. The "Long-Term Socio-Economic Forecasting for Hungary" project received grants from Iceland, Liechtenstein and Norway within the framework of EEA Grants (contract ID number: EEA C12-11). We would also like to thank two anonymous reviewers for their constructive comments on the previous version of this paper.

\section{References}

Bailey A. J., 2010. Population geographies and climate change. Progress in Human Geography, vol. 35, no. 5, pp. 686-695.

Baranyai N., Varjú V., 2015. A lakosság klímaváltozással kapcsolatos attitüdjének empirikus vizsgálata [in:] M. Czirfusz, E. Hoyk, A. Suvák (eds.), Klímaváltozás - társadalom - gazdaság. Hosszú távú területi folyamatok és trendek Magyarországon, Pécs: Publikon Kiadó, pp. 257-275.

Bartholy J., Pongrácz R., Torma CS., 2010. A Kárpát-medencében 2021-2050-re várható regionális éghajlatváltozás a RegCM-szimulációk alapján. Klíma-21 Füzetek, vol. 60, no. 1, pp. 3-13.

Birkenholtz T., 2011. Network political ecology: Method and theory in climate change vulnerability and adaptation research. Progress in Human Geography, vol. 36, no. 3., pp. 295-315.

Bobvos J., Fazekas B., Páldy A., 2015. Assessment of heat-related mortality in Budapest from 2000 to 2010 by different indicators. Időjárás, vol. 119, no. 2, pp. 143-158.

Bouzarovski S., Petrova S., 2015. A global perspective on domestic energy deprivation: Overcoming the energy poverty-fuel poverty binary. Energy Research \& Social Science, vol. 10, pp. 31-40.

Cannan E., 1895. The probability of a cessation of the growth of population in England and Wales during the next century. The Economic Journal, vol. 20, pp. 505-515.

Curtis S.E., Oven K.J., 2012. Geographies of health and climate change. Progress in Human Geography, vol. 36, no. 5, pp. 654-666.

Földházi E., 2013. Magyarország népességének várható alakulása 2011-2060 között. Demográfia, vol. 56, no. 2-3, pp. 105-143.

Giannakouris K., 2010. Regional population projections EUROPOP2008: Most EU regions face older population profile in 2030. Eurostat Statistics in focus. no. 1/2010. http://ec.europa.eu/eurostat/ documents/3433488/5564440/KS-SF-10-001-EN.PDF/d5b8bf54-6979-4834-998a-f7d1a61aa82d [10 May 2016].

IIly T., Sábitz J., Szépszó G., 2015. Validation of recent ALADIN-Climate simulations over Central Europe and Hungary. EMS Annual Meeting Abstracts, Vol. 12, EMS2015-325-1.

Intergovernmental Panel on Climate Change (IPCC) 2014. Climate Change 2014 - Synthesis Report. Summary for Policymakers. 5th Report, https://www.ipcc.ch/pdf/assessment-report/ar5/syr/ AR5_SYR_FINAL_SPM.pdf [20 July 2015].

Jankó F., Móricz Á., Papp Vancsó J., 2014. Reviewing the climate change reviewers: Exploring controversy through report references and citations. Geoforum, vol. 56, pp. 17-34.

Kovács A., Unger J., Szépszó G., 2015. Adjustment of tourism climatological indicators for the Hungarian population in assessing exposure and vulnerability to climate change [in:] Demiroğlu, O.C. et al. (eds.), Proceedings of the 4th International Conference on Climate, Tourism and Recreation - CCTR2015. Istanbul Policy Center, Istanbul, pp. 71-76. 
Kulcsár L. (ed.), 2014. Social and Economic Impact of Climate Change in Rural Hungary: Analysis and Monitoring. Sopron: Nyugat-magyarországi Egyetem Kiadó.

Leveleki M., 2015. A környezeti tudat és a környezettudatosság néhány demográfiai változó függvényében a Balaton térség népessége körében. Comitatus, no. 218, pp. 13-23.

Mcmichael A. J. (ed.), 2003. Climate change and human health. Geneva: WHO, 333 pp.

NCCS-2, 2013. The Second Climate Change Strategy for Hungary 2014-2025. http://nak.mfgi.hu/hu/ node/365 [2 June 2015].

Orosz L., Mattányi ZS., Turczi G., Kajner P., Simó B., Vikor ZS., 2015. A NATéR (Nemzeti Alkalmazkodási Térinformatikai Rendszer) fejlesztés [in:] Boda J. (ed.), Az elmélet és a gyakorlat találkozása a térinformatikában. VI. Debreceni Térinformatikai Konferencia és Szakkiállítás. Debrecen: Debreceni Egyetemi Kiadó, pp. 323-330.

Páldy A., Bobvos J., Vámos A., Kováts R. S., Hajat, S., 2005. The effect of temperature and heat waves on daily mortality in Budapest, Hungary, 1970-2000 [in:] W. Kirch, B. Menne (eds.), Extreme weather events and public health responses. New York: Springer-Verlag, pp. 99-107.

Páldy A., Bobvos J., 2010. Climate change and health - challenges for Hungary. Environmental Medicine, vol. 13, no. 1, pp. 19-29.

Páldy A., Bobvos J., 2011. A klímaváltozás egészségi hatásai. Sebezhetőség - alkalmazkodóképesség [in:] P. TAMÁS, M. BULLA (eds.), Sebezhetőség és adaptáció - A reziliencia esélyei. Budapest: MTA Szociológiai Kutatóintézet, pp. 97-114.

Páldy A., Bobvos J., 2014. Health impacts of climate change in Hungary - A review of results and possibilities to help adaptation. Central European Journal of Occupational and Environmental Medicine, vol. 20, no. 1-2, pp. 1-67.

Páldy A., Bobvos J., 2015. A hőhullámok okozta többlethalálozás vizsgálata a jelenben és a klímaváltozás következtében. Budapest: CRIGIS closing workshop, http://www.met.hu/downloads. php?fn=/KRITeR/doc/zaro/6-KRITeR_zaro_Paldy.pptx [12 May 2016].

Pálvölgyi T., Hunyady A., 2008. Common methodological framework of CLAVIER Impact Case Studies [in:] Database on the statistical-empirical interrelations between the high resolution climate indicators and the parameters of impact issues. CLAVIER Report, www.clavier-eu.org [29 May 2015].

Pálvölgyi T., Czira T., Bartholy J., Pongrácz R., 2011. Éghajlatváltozási sérülékenység-vizsgálat a CIVAS modellben [in:] J. Bartholy, L. Bozó, L. Haszpra (eds.), Klímaváltozás 2011. Budapest: MTA-ELTE, http://nimbus.elte.hu/ klimakonyv/Klimavaltozas-2011.pdf [29 May 2015].

Pieczka I., Bartholy J., Pongrácz R., André K., Kis A., Kelemen F. D., 2015. Regional climate modeling study for the Carpathian region using RegCM4 experiments [in:] Serban, G. et al. (eds.), Air and Water Components of the Environment. Cluj: Casa Cartii de Stiinta, pp. 96-101.

Popke J., 2016. Researching the hybrid geographies of climate change: reflections from the field. Area, vol. 48, no. 1, pp. 2-6.

Salih M. A. (ed.), 2013. Local climate change and society. London, New York: Routledge.

Suvák A., 2013. Environmental Ethics - What is the Drive for Urban Sustainability? [in:] Pálné Kovács, I., Scott J., Gál Z. (eds.), Territorial Cohesion in Europe: For the 70th Anniversary of the Transdanubian Research Institute. Pécs: Institute for Regional Studies, Centre for Economic and Regional Studies, Hungarian Academy of Sciences, pp. 328-337.

Suvák A., 2015. Introduction to the research project "A long term socio-economic forecasting for Hungary” (EEA-C12-11). Szentendre: REC Workshop., 26th August, 2015 [manuscript]. 
Swyngedouw E., 2013. The non-political politics of climate change. ACME: An International E-Journal for Critical Geographies, vol. 12, no. 1, pp. 1-8.

Tagai G., 2015. Járási népesség-előreszámítás 2051-ig [in:] M. Czirfusz, E. Hoyk, A. Suvák (eds.), Klímaváltozás - társadalom - gazdaság. Hosszú távú területi folyamatok és trendek Magyarországon. Pécs: Publikon Kiadó, pp. 141-166.

United Nations, Department of Economic and Social Affairs, Population Division, 2015. World Population Prospects: The 2015 Revision, Methodology of the United Nations Population Estimates and Projections. ESA/P/WP.242, http://esa.un.org/unpd/wpp/Publications/Files/WPP2015_

Methodology.pdf [10 May 2016].

Ürge-Vorsatz D., Tirado Herrero S., 2012. Building synergies between climate change mitigation and energy poverty alleviation. Energy Policy, vol. 49, pp. 83-90.

Uzzoli A., 2015. Klímamodellek a társadalmi alkalmazkodásban - A sérülékenységvizsgálatok hazai eredményei és tapasztalatai [in:] M. Czirfusz, E. Hoyk, A. Suvák (eds.), Klímaváltozás - társadalom - gazdaság. Hosszú távú területi folyamatok és trendek Magyarországon. Pécs: Publikon Kiadó, pp. 109-126.

Vág A., 2010. A környezeti migráció okai. Tér és Társadalom, vol. 24, no. 3, pp. 59-74.

Van Staden M., Musco F. eds., 2010. Local Governments and Climate Change. Sustainable Energy Planning and Implementation in Small and Medium Sized Communities. Dordrecht: Springer Varjú V., 2015. The need for an effective and integrated environmental policy: lessons from Hungary. Europa XXI, vol. 27, pp. 33-46. 
